\title{
Environmental Pollution Remediation through Solidification/Fixation of Heavy Metal Ions in Portland Cement
}

\section{Manish Kumar Goyal and Ashish Chauhan*}

NIPER, Mohali, Punjab, India

\begin{abstract}
Treatment of hazardous wastes existing as effluent using cement-based solidification/stabilization is an effective option for remediating environmental pollution. Among the various treatment techniques, it is one of the most widely acknowledged methods for treating the wastes. The primary objective of this review is to survey our current knowledge in this subject, focusing on cement chemistry, the effects of inorganic (heavy metals) and organic compounds on cement hydration and the mechanisms of immobilization of different organic and inorganic compounds.
\end{abstract}

Keywords: Environmental pollution; Heavy metals; Portland cement; Remediation

\section{Environmental Pollution}

Modern civilization equipped with advanced science and technological skill is rapidly transforming the earth to a modern world through developmental activities thereby creating numerous ecological problems and environmental pollutions associated with the hazards to human beings. These development activities have enhanced the productivity at the cost of exploitation of natural resources. The addition and accumulation of such unwanted materials or things into the environment causes destruction and degradation in ecology. The knowledge of environmental chemistry serves as a key to the understanding of water, land, air and soil pollution that may be caused through biological, chemical and physical activities [1,2].

As the amount of hazardous industrial wastes accumulates due to rapid industrialization, its planned management is required to reduce adverse impact on human beings and ecosystem. The type of waste, cost, legislation and technology limits the disposal options for industrial waste. Organic wastes with high calorific values are generally treated by oxidation or incineration, whereas inorganic wastes, commonly found in aqueous solutions or suspensions often require pretreatment before landfill. Among the industries with highest emission of heavy metals are the mining industry, metallurgical industry, chemical industry, leather industry, sugar industry, paper industries, distilleries, battery industry and thermal power plants. Toxic metals are added in the aquatic system from industrial processes, domestic sewage discharge, street dust and fossil fuel burning. All these waste streams containing heavy metal ions with very low organic content require treatment before disposal. The continuously increasing demand for raw materials and the limited availability of natural resources gave rise to the investigations of the by-products of the industry for possible reuse. Studies have shown that solidification/chemical fixation of toxic heavy metals and hazardous wastes using cement, lime, pozzolanas and other inorganic materials have been attempted to a limited extent in some of the developed countries [3]. These processes involve mixing the waste with a binder material to enhance the physical properties of the waste and to immobilize contaminants that may be detrimental to the environment. This method, effective at times, has been designated the best demonstrated available technology for some wastes and wastes forms and the United State Environmental Protection Agency has approved its use for clean me up of certain sites [3-5]. The toxic waste generated from industries containing heavy metal ions namely cadmium, nickel, mercury, zinc, copper, lead, arsenic, chromium, etc. reach the ground and contaminates soil and water [6] (Figures 1 and 2).

\section{Impact of Heavy Metals on Human Beings}

Some of the heavy metals are essential for life processes where as others like $\mathrm{Cd}, \mathrm{Pb}$, and $\mathrm{Hg}$ have no known useful biological role. All of them are injurious to living organisms at higher concentration. The heavy metals have great affinity to sulphur and attack sulphur bonds in enzymes, thus immobilizing the later. Heavy metals bind to cell membrane, affecting transport process through the cell wall. They also tend to precipitate phosphate bicompounds or catalyze their decomposition. Soil and water are characterized by varying degree of metal contamination. Air, soil and water contribute a significant

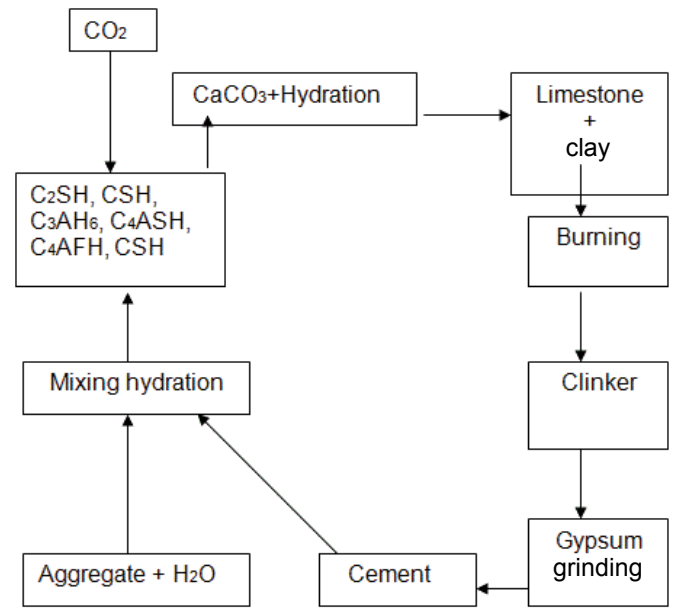

Figure 1: The cement cycle.

*Corresponding author: Ashish Chauhan, NIPER, Mohali, Punjab, India, Tel: 9464616773; E-mail: aashishchauhan26@gmail.com

Received August 20, 2015; Accepted September 09, 2015; Published September 14,2015

Citation: Goyal MK, Chauhan A (2015) Environmental Pollution Remediation through Solidification/Fixation of Heavy Metal Ions in Portland Cement. J Environ Anal Toxicol 5: 323. doi:10.4172/2161-0525.1000323

Copyright: $\odot 2015$ Goyal MK, et al. This is an open-access article distributed under the terms of the Creative Commons Attribution License, which permits unrestricted use, distribution, and reproduction in any medium, provided the original author and source are credited. 


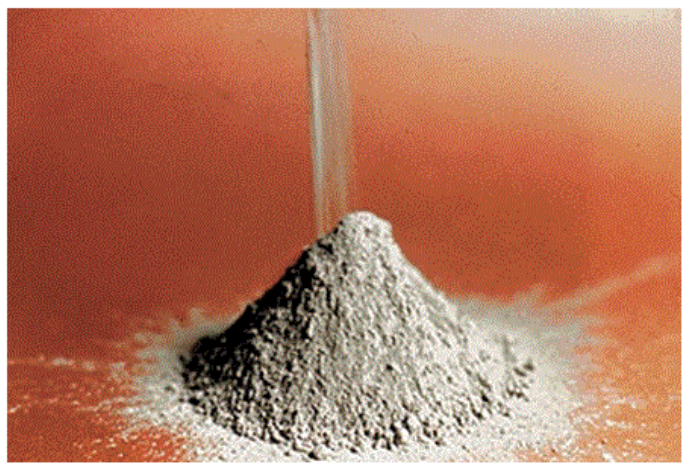

Figure 2: Portland cement.

proportion of the lead content in plant tissues. The soil and organic litter layer components of woodland ecosystems are the ultimate sinks of heavy metals in aerially contaminated areas. It is now known that the major part of the ecosystem shows high level of contamination [7].

\section{Toxic Heavy Metals}

Toxic heavy metals containing waste is generated from various process like gathering industries discharge without treatment or improper treatment in the landfills, effluent from chemical, pesticide industries. These wastes may contain many impurities in different concentrations like toxic heavy metals and other hazardous substances. As the rain falls on these waste landfills the water-soluble inorganic salts/compounds transverse to a considerable depth in soil. Due to this ground water may get contaminated and may show hazardous effect on human life as well as on the environment [8].

Arsenic is an unwanted hazardous waste generated from the processing of a variety of ores including those of copper, gold, nickel, lead and zinc. Arsenic in the past was widely used in many agricultural applications as an active ingredient in many herbicides and insecticides. Arsenic is a known poison, carcinogen and possible teratogen. It has found widespread use in agriculture and industry to control a variety of insect and fungal pests. From the 1860s, until the introduction of DDT and other organic pesticides in the 1940s, inorganic compounds of arsenic remained the dominant insecticides available to farmers and fruit growers. The use of most of these compounds has now been discontinued. However, residues, as a result of their former widespread usage, together with ongoing generation of arsenic wastes from the smelting of various ores, have left a legacy of a large number of arsenic contaminated sites. The community now faces the serious dilemmas of how best to deal with ever growing stockpiles of arsenic wastes. As arsenic is a carcinogen, environmental regulators are adopting a more stringent attitude to arsenic exposure. The world health organization revised the guideline for arsenic from 0.050 to 0.010 $\mathrm{mg} / \mathrm{l}$ in 1993. In general, there are three options available for dealing with arsenic waste streams: concentration and containment, dilution and dispersion, encapsulation of the material. Among these the most attractive option for dealing with arsenic wastes lies in encapsulation the contaminated material usually through solidification/stabilization techniques and disposing of the treated wastes in secure landfills $[9,10]$. In the environment, arsenic exists in several oxidation states: As (V), arsenate, As (III), arsenite, As (0), and As (-III), arsine. The arsenic valence state primarily depends on type and source of arsenic pollutant, environmental $\mathrm{pH}$, oxidation-reduction potential, and ligand exchange, the presence of iron oxides and other sulfur-containing compounds, as well as microbial activities [11,12]. In general, As (III) is the most toxic form of arsenic, followed by As (V), and to a lesser extent, methylated arsenic, e.g., $\mathrm{CH}_{3} \mathrm{H}_{2} \mathrm{AsO}_{3}$ [9]. Arsenic is classified in the US Environmental Protection Agency (EPA) priority pollutant list with a carcinogenicity classification (human carcinogen). The LD50 (lethal dose) is estimated to be (1-4) $\mathrm{mg}$ As/ $\mathrm{kg}$ for adult [10]. The US EPA has established a maximum contaminant level for arsenic in drinking water $(0.01 \mathrm{mg} / \mathrm{l})$ by 2006 [13]. The demand for arsenic trioxide in the manufacture of wood preservatives has increased noticeably over the last 20 years, increasing from 970 tones in 1971 to 9100 tones in 1981 and 14,300 tons in 1991 [14]. The only other area that has seen an increase in the use of arsenic is the electronics industry. High purity arsenic metal of $99.9999 \%$ or higher purity is used in the manufacture of crystalline gallium arsenide, a semi- conducting material used in optoelectronic circuitry, high speed computers and other electronic devices. Therefore, the management of hazardous wastes containing arsenic is of major public concern [15].

Cadmium is highly toxic and has been implicated in some cases of poisoning through food. Minute quantities of cadmium are suspected of being responsible for adverse changes in arteries of human kidneys. Cadmium also causes generalized cancers in laboratory animals and has been linked epidemiologically with certain human cancers. A cadmium concentration of 200 microg/l is toxic to certain fish. Cadmium may enter water as a result of industrial discharges or the deterioration of galvanized pipes [16].

Molybdenum occurs at trace levels $(<10$ micro g/L) in natural waters. In waters draining mineralized areas of waste water from processes using molybdenum, concentrations may be much higher. It is frequently used in alloy industries and in the manufacture of electronic devices owing to its high melting point, high strength at elevated temperatures high thermal conductivity and good resistance to corrosion. It is also used as a catalyst in many petrochemical and organic reactions. In solutions, molybdenum generally occurs in the form of $\mathrm{MoO}_{4}^{-2}$ ions at about $\mathrm{pH} 5$ and above [17].

An industrial waste effluent generally contains alarming amounts of copper. In industrial waste effluents it exists as soluble copper salts or as precipitated copper compounds on suspended solids. Copper is essential to human being and daily requirement for adult has been estimated to $2.0 \mathrm{mg}$. Copper salts are used in water supply systems to control biological growths in reservoirs and distribution pipes and to catalyze the oxidation of manganese. Corrosion of copper containing alloys in pipefitting may introduce measurable amounts of copper into the water in a pipe system. Excessive oral doses of copper may eventually result in lever damage.

Chromium salts are used extensively in industrial processes and are present in the discharge of wastes. Chromium may exist in aqueous medium in both the hexavalent and the trivalent state although the trivalent form rarely occurs in potable water. Chromium enters a water supply through industrial wastes from metal plating baths and from industrial cooling towers where chromate is used to inhibit metal corrosion. Pollution by chromium and its compounds is of considerable concern as the metal is highly reactive and has found widespread use in leather tanning, electroplating metal finishing and chromate preparations processes. Two predominant forms of chromium namely $\mathrm{Cr}$ (III) and $\mathrm{Cr}$ (VI) occur in aqueous systems. Over exposure of chrome workers to chrome dust and mists has been related to irritation and corrosion of the skin and respiratory track and probably to lung carcinoma. In digestion may cause epigestric pain, nausea, vomiting, severe diarrhea and hemorrhage. Its disposal 
in a hydrologic environment can cause environment risk due to the mobility of the metal ions. These metal ions may get mixed in surface water and ground water system, which may be determined to human being and environment [18-20]. One of the best methods for their disposal is to transform them into a water insoluble material or at least to a form in which chances of water leachability are extremely low [21,22] (Table 1).

\section{Environmental Pollution Remediation Measures}

Various conventional and unconventional techniques have been explored for the environmental pollution remediation but among the several technologies adopted for pollution control the following two methods have been widely used all over the world.

\section{Adsorption for the removal of toxic pollutants from water/ waste water}

Adsorption was first observed by CW Scheele in 1773 for gases and subsequently for solutions by Lowitz in 1785 and Kraemer in 1930, now it is recognized as a significant phenomenon in most natural physical, biological, and chemical processes. Absorption, is a process in which the molecules or atoms of one phase interpenetrates uniformly to form a 'solution' with the second phase. The term sorption includes both adsorption and absorption, is a general expression for a process in which a component moves from one phase to be accumulated in another particularly for cases in which the second phase is solid. Adsorption involves the interphase accumulation or concentration of substances at a surface or interface. The process can occur at an interface between any two phases, such as liquid -liquid, gas liquid, gas -solid or liquid soild interface. The material being concentrated or adsorbed is the adsorbate, and the adsorbing phase is termed the adsorbent [23-25].

\section{Solidification/stabilization for the fixation of toxic wastes in cement}

Stabilization and solidification (S/S) is known as one of the most popular technologies for treating and disposing of hazardous wastes. It is a widely accepted treatment process for a broad range of waste generally the metal concentrations in these wastes are too low for economic recovery but high enough to represent toxicity hazards [26,27]. Ludwiq et al. [28] found that ordinary Portland cement is a material found to be most useful for the purpose of solidification/ stabilization due to its ability for fixation and immobilization of heavy metals. These S/S technologies using cementitious materials have been used for decades as a final treatment step prior to the disposal of both radioactive and chemically stable forms, resulting in better environmental acceptance.

Physical stabilization refers to the process of solidification improves engineering properties, such as bearing capacity, trafficability and permeability of stabilized waste forms. Chemical stabilization is the alteration of the contaminants' chemical form so that leachability is eliminated or substantially reduced [29-31]. Various technologies have been developed to reduce the release of toxic species into the environment [32]. The United State Environmental Protection Agency also recognizes solidification/stabilization as "The Best Demonstrated Available Technology" for land disposal of most toxic elements [33-35]. Portland cement can be modified for suitable S/S process using flyash, lime slag soluble silicates [36,37]. One of the most difficult problems in this process is that the hydration of cementitious materials is too retarded to set and harden enough due to the inhibition of hydration reaction of heavy metals in a landfill area. A number of researchers have reported the effect of metals and other inorganic compounds on the setting, mechanical and engineering properties of cement [38-43]. Lime and Portland cement are relatively inexpensive having consistent properties. Cement and $\mathrm{Ca}(\mathrm{OH})_{2}$ may also be mixed with each other and with a variety of other reactive wastes including slag, fly ash to form solid matrices. Physical containment is most important for mobile liquids, dusts, sludges and solutions because cement can accommodate wet wastes, neutralize acids and tolerate salts. The wastes can frequently be dispersed throughout a cementitious matrix. The cement affords both physical resistance to leaching and a definite chemical immobilization potential. Cement provides a strongly alkaline internal environment. $\mathrm{Ca}(\mathrm{OH})_{2}$ and calcium silicate hydrogel $(\mathrm{C}-\mathrm{S}-\mathrm{H})$ are available to buffer the $\mathrm{pH}$ to about 12.4 at $18^{\circ} \mathrm{C}$ in the short term any alkali in the cement or waste tends to raise the $\mathrm{pH}$ above 12.4 because counter ions other than $\mathrm{OH}^{-}$are relatively insoluble: chloride and nitrate are the main exceptions. Hence the $\mathrm{pH}$ of the lime or cement conditioned matrix is likely to be within the range 12.4-14.0 and is well buffered by the cement solids [44-47].

Cement based S/S is an established and proven technology that prevents contaminants moving into the environment from treated material. This immobilization occurs through physical and chemical bonding with the contaminants and, in many cases, chemical changes within the contaminants themselves. Immobilizing contaminants within treated waste prevents human, animal, and plant exposure to hazardous constituents. Cement based S/S is done by mixing Portland cement into the waste as it is generated by industry to make the waste safe for land disposal. Recent studies have shown that solidification/ stabilization $(\mathrm{s} / \mathrm{s})$ process are viable for most metallic waste involves mixing the waste with a binder material to enhance the physical properties of the waste and to immobilize contaminants that may be detrimental to the environment $[48,49]$. Several binder systems are currently available and widely used for solidification/stabilization. The two main constituents of most commercial fixing agents are cementitious materials (Portland cement, fly ash and lime) and sodium silicate, but increasing research efforts are being directed towards using cement-based binders. Many studies showed that alkalis accelerate early hydration, resulting in increasing the initial strength of Portland

\begin{tabular}{|c|c|c|c|}
\hline S No & Heavy metals & Sources & Health effect \\
\hline 1 & $\mathrm{~Pb}$ & Leaded gasoline, battery industry & Nausia, Brain and kidney damage, mental retardation in adult \\
\hline 2 & $\mathrm{Cu}$ & Metal plating industry & Carcinogenic Wilson's disease \\
\hline 3 & $\mathrm{Cr}$ & Electroplating, paint industry, metal plating & Carcinogenic Skin damage \\
\hline 4 & $\mathrm{Cd}$ & Electroplating waste, Ni-Cd batteries & Kidney damage, sterility on males, flu-like disorder, high blood pressure and Itai-Itai, hypertension \\
\hline 5 & $\mathrm{Ni}$ & Ni plating industry & Carcinogenic disease \\
\hline 7 & $\mathrm{Hg}$ & Electrochemical industry & Gastro-intestine disorders, brain damage \\
\hline
\end{tabular}

Table 1: Effect of heavy metals on human health. 
cement, but decreasing compressive strength later. Singh et al. reported that the addition of alkali by pass kiln dust accelerated by hydration, causing decreased porosity in the hardened structure and increased compressive strength for Portland cement and blast furnace slagblended cement. Many researches have studied the effect of heavy metals on cement hydration [50-52]. Oshiro et al. reported that the hydration of cement was retarded in presence of $\mathrm{Zn}, \mathrm{Pb}$ and $\mathrm{Cu}$ [38].

Trussel and Spence and Mattus and Mattus; included the discussion of qualitative effect on $\mathrm{Zn}, \mathrm{Pb}$ and $\mathrm{Cr}$ on the cement properties [26,53]. Arliquie and Grandet reported that an amorphous layer of $\mathrm{Zn}(\mathrm{OH})_{2}$ is formed during hydration of $\mathrm{C}_{3} \mathrm{~S}$ phase in the presence of $\mathrm{Zn}$, thus retarding the hydration of this phase [54]. Hamilton and Sammes analyzed cement doped with $\mathrm{ZnO}(1: 1$ to $2 \%)$ and this compound seems to form protective layer that inhibits the normal hydration of cement grains [55]. Mollah et al. suggested that the formation of a surface layer of $\mathrm{CaZn}_{2}(\mathrm{OH})_{6} \cdot \mathrm{H}_{2} \mathrm{O}$ which does not allow the transport of water to $\mathrm{C}_{3} \mathrm{~S}$ phase [56].

Ortega et al. studied that the effect of zinc nitrate on the hydration of cement and observed that $60 \%$ of the added water is lost after the exposition of the product in open containers. They indicated that most of the added water does not react with the clinker to form hydration products. He also suggested that lead is present as sulfate or hydrosulfate species, this fact can be related to the absence of ettringite reported by Tashiro et al. $[57,58]$.

Zivica studied the long-term behavior of cement mortars containing $\mathrm{PbO}$ and $\mathrm{Cr}_{2} \mathrm{O}_{3}$ under the action of a $\mathrm{NaCl}$ solution they observed a greater degradation of the mortar compared to the control sample [59]. Mollah et al. suggested that chromium compounds are not formed on the hardened surface cement, these compounds were dispersed below the surface of the ordinary Portland cement matrix and chromium ions can substitute the silicon in the C-S-H [56]. A lot of work has been reported concerning the binding mechanism during $\mathrm{S} / \mathrm{S}$ processes.

S/S treatability studies and mix designs include tests to determine the physical and chemical properties of the treated material. Using leaching and extraction tests scientists can determine the amounts of hazardous constituents that can leach from treated waste under worst-case scenarios. Physical tests such as compressive strength are used to determine the absence of free liquids in treated waste and also construction properties, if the treated material is destined for reuse or land disposal. A flux of hydroxyl ions is produced within seconds when water is added to cement, which allows the precipitation of several metal hydroxides. These insoluble precipitates of toxic elements such as lead, chromium and arsenic get into the structures of hydrated compounds of the elements especially calcium sulfoaluminates and get adsorbed rigidly over the resulting hydrated phases. This results in the fixation of toxic elements in the slowly forming calcium silica hydrate gel structure $[60,61]$. Stabilization procedure is rather complex, that involves either binding or adsorption of heavy metal ionic species in the matrix. If the waste is mixed with anhydrous cement and water there is the possibility of ions incorporation in the cement structure during the hydrolysis process. Heavy metal ions could bind with the cement by the process of chemisorptions, precipitation, surface absorption, and "capturing" inside the matrix, chemical incorporation with the combination of mentioned possibilities [62-64]. Various workers have reported the effect of many individual metal ions on physical, chemical and engineering properties of cement based system like molybdenum [65] chromium $[5,38,56,58,66]$ copper, arsenic cadmium, lead, zinc etc. $[6,42,43,52,60]$.

\section{Advantages of Solidification/Fixation Techniques}

Due to the introduction of recent stringent regulations, alternative methods to mono or co-disposal, without domestic refuse of toxic wastes, there is a growing interest among the waste disposal industry and controlling bodies in the utilization of solidification/stabilization processes for the disposal of toxic wastes. Solidification/Stabilization may provide (a) Overall protection of human health and the environment, (b) compliance with applicable or relevant and appropriate requirement, (c) long term effectiveness, (d) reduction of toxicity, mobility and volume, (e) short term effectiveness, (f) implementability. In brief, $\mathrm{S} / \mathrm{S}$ treatment has demonstrated (a) protectiveness, (b) complies with land disposal restrictions, (c) demonstrated long term effectiveness through treatability testing and monitoring, (d) reduces toxicity and mobility of hazardous constituents, (e) can be carried out safely for site workers and surrounding community, with in-situ treatment reducing hazardous posed by waste transportation, and (f) cost-effectiveness. Among solidification /stabilization formulations investigated, the use of cement and flyash appears to be the least successful.

\section{Fixation of Heavy Metals in Portland Cement}

Fixation of metals using Portland cement and fly ash believed to occur via the combination of producing an impermeable monolith, which reduces the surface area available for leaching, creating a high $\mathrm{pH}$ environment that generally limits the solubility of most metals and limits the formation of metal complexes with the cement/flyash matrix [65-66]. Akhter et al. have raised serious concerns about the benefits of using flyash [67]. The work of Akhter et al. yielded results that indicated that the leachability of arsenic is much greater from those solidification/ stabilization formulations that contained fly ash. The use of fly ash is associated with it the problem of bulking. Since fixed waste is generally buried in a landfill, it is desirable, for cost and space reasons, to bury the smallest quantity possible. Bulking due to treatment by silicates and metal hydroxides is low, approximately $20 \%$ or less, while bulking resulting from treatment with cement/ flyash is high, approximately $100 \%$ [68]. The solidification /stabilization of arsenic is most successful when cement, cement and iron, cement and lime or combinations thereof, are used [69-71]. Akhter et al. investigated various methods for the immobilization of arsenic, cadmium, chromium, and lead in contaminated soil. The soil under investigation had an arsenic concentration of $12,200 \mathrm{ppm}$. The suitability of various combinations of Portland cement, fly ash, blast furnace slag, lime and silica fume were investigated. The only sample in the study showing reasonable leaching performance was that using Portland cement alone, at a dosage of 1.0 part soil in 0.44 part cement. While the research to date indicates that the use of iron, lime and cement can be beneficial in the solidification/stabilization of arsenic, it is difficult to differentiate between the results obtained by the numerous researchers and draws any firm conclusions on which $\mathrm{S} / \mathrm{S}$ processes are the most efficient and effective [72-77]. Despite the extensive efforts by several researchers, there is very less data reported in the literature especially about the quantitative effects of addition of different metal ions on initial and final setting times of ordinary Portland cement, therefore, efforts have been made to fill void in this data. A realistic goal is to minimize the risk by treatment and disposal of these wastes by transforming the containment into less hazardous compounds. In this technique metal ions are converted into insoluble salts which do not leach into water at appreciable risk also the technique is cost effective, simple and easy to apply (Hamilton and Sammes). Ordinary Portland cement is being used as an immobilizing agent for heavy metal ion since the late $19^{\text {th }}$ century worldwide. It has very well defined final property relatively 
economical and widely available its hydration product are very durable and well known to general public. Although the chemistry behind the hydration of Portland cement is quite complex and the mechanism of its various characteristic are not completely established but these difficulty can be minimized through experienced based quality standard and specifications which can avoid any significant effect on product quality which are otherwise difficult to predict Lea [78]. Cement based Solidification/ Stabilization (S/S) has been effectively demonstrated as a treatment technique to isolate hazardous waste from the environment (EPA Report) [18]. In this technique impurities are blended with cement to obtain desired characteristic in the final product [79]. To control setting characteristic and to provide a chemical or physical environment to check the leaching of toxic containment to the environment a large number of investigations have been performed to determine the effects of various inorganic compounds on physical chemical and engineering properties of cement and cement based binder systems $[21,80,81]$. Ordinary Portland cement as well as modified Portland cement using fly ash, lime, slag etc. can be used for this purpose. Normally an excess of water, beyond that required for complete hydration of the cement, is needed to achieve the necessary plasticity or fluidity for mixing and also to achieve economic loadings of wet wastes. The durability testing of cement bonded hazardous substances is usually done by leaching of crushed product having a definite particle size. Besides water or other solvents e.g., citric acid, to simulate the effect of soil acids or of acid rain [82-85]. Leaching tests can also be used for durability testing, although they do not reflect in all cases the real situation, where a bulky structure is attacked instead of a powder [77,86-90]. Amal et al. investigated the microstructure of cementitious wastes containing different metal ions like $\mathrm{Pb}, \mathrm{Cd}$, As and $\mathrm{Cr}$ and examined the implications of the microstructure on the leaching of the heavy metal ions [91]. In recent years the characterization of leaching behavior by testing materials under $\mathrm{pH}$ controlled conditions has increased significantly [92]. This has been prompted by the fact that $\mathrm{pH}$ is one of the most crucial parameters governing the release of constituents from the solid phase into solution. For a wide range of granular materials this type of characterization of leaching has allowed identification of key controlling factors. It has facilitated geochemical modeling and as a result of these actions. It can lead to better choices in waste management by identifying minimal release conditions that can be guaranteed for long periods of time this type of characterization has been extended into the field of construction products and stabilized waste to identify in a similar manner controlling factors in cementbased products and cement-stabilized waste. Although micro structural development in cement paste and concrete has been widely studied in recent years, the same cannot be said for cement -solidified hazardous wastes. As microstructural development is known to influence the performance characteristics of Portland cement concretes it follows that the same might apply to solidified waste forms.

Fly ash and blast furnace slag and a large number of other industrial wastes of siliceous nature are available in huge quantities in different parts of the country, which could form a very vital source for chemical fixation of heavy metal ions from industrial effluents. Currently most of the R \& D efforts are being directed towards the solidification/ stabilization of organic wastes using cement based binders. The two principal constituents of most commercial fixing agents are cementitious materials (Portland cement, fly ash, lime and sodium carbonate) but a combination of cement and soluble silicates was found to be best binder in the solidification of a largely inorganic residue with trace concentrations of organic contaminants [93]. Many researchers studied the effect of heavy metals on solidification of cement [94-99].

\section{Conclusions}

In the $\mathrm{S} / \mathrm{S}$ treatment of organic compounds using cement alone, the contaminants are physically trapped within the pores in the cement matrix and are not reacting with the polar inorganic components of the cement constituents. Use of adsorbents such as organophilic clays and activated carbon, either as a pretreatment or as additives in the cement mix, can more effectively immobilize organic compounds in the cement matrix. Thus the building products like bricks, blocks and tiles etc made by using fly ash, cement and heavy metal ions are cost effective, easy to use, long service life and environment friendly.

\section{References}

1. Biczok I (1967) Concrete Corrosion and Concrete Protection, Chemical Publishing Company, New York, USA.

2. Park CK (2000) Hydration and solidification of Hazardous waste containing heavy metals using modified cementitious materials. Cem Concr Res 30: 429-435.

3. Barth EF (1990) Solidification / stabilization: Mechanism and Applications GCHSRC's Second Annual Symposium, Feb. 15-16 Beaumont, Tk 1-6.

4. Corner JR (1990) Chemical Fixation and Solidification of Hazardous wastes, Van Nostrand- Reinhold, New York, USA.

5. Roy A, Eaton HC, Cartledge FK, Tittle Baum ME (1991) Solidification Stabilization of a Heavy metal sludge by a Portland cement/ fly ash binding mixture. Hazardous waste and Hazardous materials 8: 33-41.

6. Deja J (2002) "Immobilization of $\mathrm{Cr}^{6+}, \mathrm{Cd}^{2+}, \mathrm{Zn}^{2+}$ and $\mathrm{Pb}^{2+}$ in alkali activated slag binders. Cem Concr Res 32: 1971-1979.

7. Cullinane MJ, Jones LW, Malone PG (1986) Handbook for Stabilization/ Solidification of Hazardous Waste, EPA/540/2-86-001, USEPA, Risk Reduction Engineering Laboratory, Cincinati, OH, USA.

8. West TS, Nurenburg HW (1988) The Determination of Trace Metals in Natura Waters; Blackwell Scientific Publications, Oxford, England.

9. RTI (Research Triangle Institute) (1998) Toxicological Profile for Arsenic: draft, prepared for US Department of Health and Human Services, Public Health Service, Agency for Toxic Substances and Disease Registry, Atlanta, Georgia, USA

10. Pontius FW, Brown KG, Chen CJ (1994) Health implications of arsenic in drinking water. J Am Water Works Assoc 86: 52-63.

11. Ferguson JF, Gavis J (1972) A review of the arsenic cycle in natural waters Water Res 6: 1259-1274.

12. Matera V, Hecho IL (2001) Arsenic behavior in contaminated soils: mobility and speciation. In: HM Selim and DL Sparks, Editors, Heavy Metals Release in Soils, CRC Press, Boca Raton, Florida. pp. 207-235

13. Federal Register (2001) National Primary Drinking Water Regulations; Arsenic and Clarifications to Compliance and New Source Contaminants Monitoring Final Rule. Environmental Protection Agency, 40 CFR Parts 9, 141, and 142.

14. Loebenstein JR (1992) Proceedings, Workshop on Removal, Recovery, Treatment and Disposal of Arsenic and Mercury. USEPA Report EPA/600/R-92/ 105: 8-9.

15. Kameswari KSB, Bhole AG, Paramasivam R (2001) Evaluation of solidification (S/S) process for the disposal of arsenic bearing sludges in landfill sites. Environ Eng Sci 18: 167-176.

16. Shawabkeh RA (2005) Solidification and stabilization of cadmium ions in sandcement-clay mixture. J Hazard Mater 125: 237-243.

17. Kindness A, Lachowski EE, Minocha AK, Glasser FP (1994) Immobilization and Fixation of Molybdenum (VI) by Portland cement. Waste Management 14: 97-102.

18. USEPA (1991) The Superfund innovative technology Evaluation Program Technology Profiles, EPA, Washington DC, USA.

19. USEPA (1994) Natural Attenuation of hexavalent Chromium in Groundwater and Soils, EPA, Wahington DC, USA.

20. James BR (1996) Peer reviewed: the challenge of remediating chromiumcontaminated soil. Environ Sci Technol 30: 248A-251A. 
Citation: Goyal MK, Chauhan A (2015) Environmental Pollution Remediation through Solidification/Fixation of Heavy Metal lons in Portland Cement. J Environ Anal Toxicol 5: 323. doi:10.4172/2161-0525.1000323

Page 6 of 7

21. Cote PO, Bridle TR, Hamilton DP (1984) Evaluation of Pollutant Release from Solidified Aqueous Waste Using a Dynamic Leaching Test, Hazardous Waste and Environmental Emergencies, Houston TX, USA.

22. Cote' P, Constable T, Stegemann J, Dayal R, Sawell S, et al. (1988) Guide for the Selection of leaching tests (in preparation), prepared for USEPA, Risk Reduction Engineering Laboratory, Cincinnati, $\mathrm{OH}$, by the Waste Water Technology Center, Burlington, Ontario, Canada.

23. Saygideger S, Gulnaz O, Istifli ES, Yucel N (2005) Adsorption of Cd(II), Cu(II) and $\mathrm{Ni}(\mathrm{II})$ ions by Lemna minor L.: effect of physicochemical environment. J Hazard Mater 126: 96-104.

24. Goel J, Kadirvelu K, Rajagopal C, Kumar Garg V (2005) Removal of lead(II) by adsorption using treated granular activated carbon: batch and column studies. J Hazard Mater 125: 211-220.

25. Dickey FH (1955) Specific Adsorption. 59: 695-707.

26. Trussel S, Spence RD (1994) A Review of Solidification / Stabilization Interferences. Waste management. 14: 507-519.

27. Adaska WS, Tresouthick SW, West PB (1991) Solidification and Stabilization of wastes using Portland cement, Portland cement Association Skokie IL, USA.

28. Ludwig C, Ziegler F, Johnson CA (1997) Heavy metal Binding Mechanisms in cement Based waste materials, Waste materials in construction-putting Theory into Practice, Edited by Goumans, Senden, Vandersloot, Studies in Environmental Science 71, Elsevier Science : 355-364.

29. Hills CD, Simon Pollard JT (1997) The influence of interference effects on the mechanical microstructural and fixation Characteristics of cement-solidified hazardous waste forms. Journal of Hazardous Materials 52: 171-191.

30. Myers TE (1986) A Simple Procedure for Acceptance Testing of Freshly Prepared Solidified Waste, Hazardous and Industrial Solid Waste Testing: Fourth Symposium, ASTM STP 886, JK Petros Jr., WJ Lacy and RA Conway, eds., American Society for Testing and Materials, Philadelphia, PA.

31. Woods H (1968) Durability of Concrete, ACI Monograph 4, American Concrete Institute, Detroit, MI, USA.

32. Mayers TE, Eappi ME (1992) Laboratory evaluation of Stabilization/ Solidification technology for reducing the mobility of heavy metals in New Bedford harbor superfund site sediment stabilization of hazardous radioactive and mixed wastes, 2nd edn. ASTM publication Philadelphia PA 304.

33. USEPA (1986) Test Method for Evaluating Solid Wastes, SW-846, 3rd edn Office of Solid Waste and Emergency Response, Washington DC, USA.

34. USEPA (1996) Hazardous Waste characteristics Scoping Study, United States Environmental Protection Agency office of solid Waste, Washington DC, USA.

35. Jones LW, Malone PG (1982) Physical Properties and leach Testing of Solidified/Stabilized industrial Waste, EPA-600/2-82-099 (NTIS PB83-147983), USEPA, Municipal Environmental Research Laboratory, Cincinnati, $\mathrm{OH}$.

36. Laforest G, Duchesne J (2005) Immobilization of chromium (VI) evaluated by binding isotherms for ground granulated blast furnace slag and ordinary Portland cement. Cem Concr Res 35: 2322-2332.

37. Trezza MA, Ferraiuelo MF (2003) Hydration study of limestone blended cement in the presence of hazardous wastes containing $\mathrm{Cr}(\mathrm{VI})$. Cem Concr Res 33: 1039-1045.

38. Tashiro C, Oba J (1979) The Effects of $\mathrm{Cr}_{2} \mathrm{O}_{3}, \mathrm{Cu}(\mathrm{OH})_{2}, \mathrm{ZnO}$ and $\mathrm{PbO}$ on the compressive strength and the hydration of hardened $\mathrm{C}_{3} \mathrm{~A}$ Paste. Cem Concr Res 9: 253- 258 .

39. Minocha AK, Jain N, Verma CL (2003) Effect of Inorganic Materials on the Solidification of Heavy metal Sludge. Cem Concr Res 33: 1695-1701.

40. Alunno Rosseti V, Medici F (1995) Inertization of toxic metals in cement matrices: effects on hydration and hardening. Cem Concr Res 25: 1147-1152.

41. Fernandez Olmo I, Chacon E, Irabien A (2001) Influence of Lead, Zinc, Fe(III) and $\mathrm{Cr}(\mathrm{III})$ oxide on the setting time and strength development of Portland cement. Cem Concr Res 31: 1213-1219.

42. Minocha AK, Goyal MK, Kumar P (2006) Fixation of Arsenic (III) ions in Ordinary Portland Cement, New Build. Mater and Constr World 11: 128-135.

43. Minocha AK, Kumar P, Goyal MK, Verma CL (2004) Immobilization of Toxic Metals in cement based system- case studies, New Build. Mater and Constr World 10: 44-51.
44. Mehta PK (1987) Concrete Structure, Properties and Materials, Prentice Hall, Inc. Englewood Cliffs, NJ, USA.

45. Taylor HFW (1964) The Chemistry of Cement, Vol. (II) Academic press, New York, USA.

46. Taylor HFW (1997) Cement Chemistry, 2nd edn, Thomas Telford, UK.

47. Richardson IG (1999) The nature of CSH in hardened cements. Cem Concr Res 29: 1131-1147.

48. Nocun W, Goteborg MJ (1997) Studies on Immobilization of heavy metals in Cement Paste-C-S-H leaching behavior, Proceedings of the 10th international Congress on the chemistry of cement, Sweden 4,4iv,043.

49. Glasser FP (1993) Chemistry of cement solidified waste forms chemistry and microstructure of solid waste forms, Lewis publishers Chelsea, MI-PI.

50. Gervais C, Ouki SK (2002) Performance study of cementitious systems containing zeolite and silica fume: effects of four metal nitrates on the setting time, strength and leaching characteristics. J Hazard Mater 93: 187-200.

51. Minocha AK, Kumar P, Singh J, Goyal MK, Aggarwal LK (2005) Influence of copper(II), lead(II) and cadmium(II) metal ions on the setting time of ordinary Portland cement. Indian J Env Prot 25: 365-368.

52. Minocha AK, Kumar P, Singh J, Aggarwal LK, Verma CL (2005) Effect of molybdate (II), chromium (III) and (VI) metal ions on the setting time of ordinary Portland cement. Indian J Env Prot 24: 771-774.

53. Mattus $\mathrm{CH}$, Mattus AJ (1996) Literature review of the interaction of select inorganic species on the set and properties of cement and methods of abatement through pretreatment in T.M

54. Arliquie G, Grandet J (1990) Etude de l'hydration du ciment en presence de zinc, influence de la teneur en gypse. Cem Concr Res 20: 346-354.

55. Hamilton IW, Sammes NM (1999) Encapsulation of steel foundry dusts in cement mortar. Cem Concr Res 29: 55-61.

56. Mollah MYA, Tsai YN, Hes TR, Cocke DL (1992) An FTIR, SEM and EDS investigation of solidification/stabilization of chromium using Portland cement Type V and Type IP. J Hazard Mater 30: 273-283.

57. Ortego JD (1990) Spectroscopic and leaching studies of solidified toxic metals $\mathrm{J}$ Hazard Mater 24: 137-144.

58. Tashiro C, Oba J, Akama K (1979) The effect of several heavy metal oxides on the formulation of ettringite and the microstructure of hardened ettringite. Cem Concr Res 9: 303-308.

59. Zivica V (1996) Resistance of cement mortars containing heavy metal oxides exposed to long term repeated action of chloride solution. Constr Buil Mater 10: $515-519$.

60. Palomo A, Palacios M (2003) Alkali Activated cementitious materials: alternative matrices for the immobilization Hazardous waste Part II. Stabilization of $\mathrm{Cr}$ and $\mathrm{Pb}$. Cem Concr Res 33: 289-295

61. Leist M, Casey RJ, Caridi D (2003) The fixation and leaching of cement stabilized arsenic. Waste Manag 23: 353-359.

62. Dermatas D, Moon DH, Menounou N, Meng X, Hires R (2004) An evaluation of arsenic release from monolithic solids using a modified semi-dynamic leaching test. J Hazard Mater 116: 25-38.

63. Pourbaix M (1966) Atlas of Electrochemical Equilubria in Aqueous Solutions, Pergamon Press, Oxford, UK

64. Ortego JD, Jackson S, Yu GS, Whinney HMC, Cocke DL (1989) Solidification of hazardous substances. A TGA and FTIR study of Portland Cement containing metal nitrates. J Environ Sci Health Part A 24: 589-602.

65. Barna LT, Imyim A, Barna R (2004) Long term predication of the leaching behavior of pollutants from solidified wastes. Advances in Env Res 8: 697-711.

66. Cocke DL, Mollah MYA (1993) The chemistry and leaching mechanisms of hazardous substances in cementitious solidification / stabilization systems, in: R.D. Spence (Ed.), Chemistry and Microstructure of solidified Waste Formes, Lewis Publishers, Boca Raton, FL, USA.

67. Akhter H, Cartledge FK, Miller J, McLearn M (2000) Treatment of arseniccontaminated soils. I: soil characterization. J Environ Eng 126: 999-1003.

68. Ilic M, Miletic S, Brceski I, Milic D, Solidification/ Stabilization of toxic metal ions in Portland cement and Portland flyash cement matrix. 
Citation: Goyal MK, Chauhan A (2015) Environmental Pollution Remediation through Solidification/Fixation of Heavy Metal lons in Portland Cement. J Environ Anal Toxicol 5: 323. doi:10.4172/2161-0525.1000323

69. TEPA (2001) Study to Minimize the Materials for Solidification of Hazardous Fly Ash, Taiwan. Environmental Protection Administration, Taipei, Taiwan.

70. Artiola JF, Zabcik D, Johnson SH (1990) In situ treatment of arsenic contaminated soil from a hazardous industrial site: Laboratory studies. Waste Manage 10: 73-78.

71. Dutre V, Vandecasteele C (1995) Solidification/stabilization of arseniccontaining waste: leach tests and behaviour of arsenic in the leachate. Waste Manage 15: 55-62.

72. Voigt DE, Brantley SL, Hennet RJC (1996) Chemical fixation of arsenic in contaminated soils. Appl Geochem 11: 633-643.

73. Miller J, Akhter H, Cartledge FK, McLearn M (2000) Treatment of arseniccontaminated soils. I: soil characterization. J Environ Eng 126: 1004-1012.

74. Fuessle RW, Taylor MA (2000) Stabilization of arsenic- and barium-rich glass manufacturing waste. J Environ Eng 126: 272-278.

75. Sanchez F, Garrabrants AC, Vandecasteele C, Moszkowicz P, Kosson DS (2003) Environmental assessment of waste matrices contaminated with arsenic. J Hazard Mater 96: 229-257.

76. Shih CJ, Lin CF (2003) Arsenic contaminated site at an abandoned copper smelter plant: waste characterization and solidification/stabilization treatment. Chemosphere 53: 691-703.

77. Vandecasteele C, Dutré V, Geysen D, Wauters G (2002) Solidification/ stabilisation of arsenic bearing fly ash from the metallurgical industry. Immobilisation mechanism of arsenic. Waste Manag 22: 143-146.

78. Lea FM (1971) The Chemistry of Cement and Concrete, New York: Chemical Publishing.

79. Cseteneyi L, Zement Kalk Gips (1992) 48: 59-69.

80. Duchesne J, Laforest G (2004) Evaluation of the degree of Crions immobilization by different binders. Cem Conc Res 34: 1173-1177.

81. Slegmann JA, Buenfeld NR (2002) Prediction of unconfined compressive strength of cement paste with pure metal compound additions. Cem Concr Res 32: $903-913$

82. Carteldge FK, Buttler LG, Chalasani D, Harvill C, Frank PE, et al. (1990) Immobilization mechanisms in solidification/ Stabilization of $\mathrm{Cd}$ and $\mathrm{Pb}$ salts using Portland cement fixing agents. Environ Sci Technol 24: 867-873.

83. Machpee DE (1990) PRC-Pore Reduced Cement: High Density Cement Pastes Following Fluid Extraction. Advances in Cement Research 3: 135-142.

84. Atkin M, Glasser FP, Kindness A, Macphee DE (1991) Solubility data for cement hydrate phases $\left(25^{\circ} \mathrm{C}\right)$. DOE/HMIP/PR/91/032; Aberdeen University, Aberdeen, Scotland. UK.
85. Tashiro C, Takashaki H, Kamaya M, Hirakida I, Yashida R (1977) Hardening properties of cement mortar adding metal compounds and solubility of heavy metal from hardened mortar. Cem Concr Res 7: 283-290.

86. Spence RD (1993) Chemistry and Microstructure of Solidified Waste Forms Lewis Publishers, Boca Raton, FL, USA.

87. Wang SY, Vipulanandan C (1996) Leachabiltity of lead from solidified cementflyash binders. Cem Concr Res 26: 895-905.

88. Shin HS, Koo JK, Kim JO (1990) Leaching characteristics of heavy metals from solidified sludge under sea water conditions, Hazard. Waste Hazard Mater 7 : 261-271.

89. van der Sloot HA (2002) Characterization of the leaching behaviour of concrete mortars and of cement-stabilized wastes with different waste loading for long term environmental assessment. Waste Manag 22: 181-186.

90. Hillar SR, Sangha CM, Plunkett BA, Walden PJ (1999) Long term leaching of toxic trace metals from Portland cement concrete. Cem Concr Res 29: 515521.

91. Halim CE, Amal R, Jason DB, Scott A, Low G (2004) Implication of the structure of cementitious wastes containing $\mathrm{Pb}(\mathrm{II}), \mathrm{Cd}(\mathrm{II}), \mathrm{As}(\mathrm{V})$ and $\mathrm{Cr}(\mathrm{VI})$ on the leaching of metals. Cem Concr Res 34: 1093-1102.

92. Van der sloot HA, Quevauviller HL (1997) Harminization of leaching/ extraction tests. Studies in Environmental science. Amsterdam: Elsevier science. 70: 292.

93. Chalsani D, Cartledge FK, Eaton HC, Tittebaum ME, Walsh MB (1986) The effect of ethylene glycol on a cement based solidification process. Hazardous wastes Hazardous materials 3: 167-173.

94. lopez-Delgado A, Perez C, Lopez FA (1998) Sorption of heavy metals on blast furnance sludge. Water Research 32: 989.

95. Soundrajan R, Barth EF, Gibbons JJ (1990) HMCRI's. Hazardous materials control 3: $42-45$

96. Youn JH, Jeong BG, Lee HM, Chung HS, Park C (1995) Immobilization's of heavy metals using ordinary Portland cement and lime - rice husk ash. J Korean Solid wastes Eng Soc 12: 645-653.

97. Zamorani E, Sheikh IA, Rossa MD, Serrini G (1989) Physical properties and leachabilities of M.L.W. stream containing $\mathrm{Cr}, \mathrm{Ni}$ and $\mathrm{Cd}$ immobilized in a cement matrix, scientific basis for Nuclear Waste Management XII, Proceeding of Material Research Society Symposium 127: 489-494.

98. Minocha AK, Goyal MK (2014) Solidification/Fixation of nickel lons in Ordinary Portland Cement. J Chem Eng Process Technol 5: 5.

99. Minocha AK, Goyal MK (2013) Effect of immobilization of Cadmium (II) ions on the hydration of ordinary Portland cement. J Chem Eng Process Technol 4: 7. 